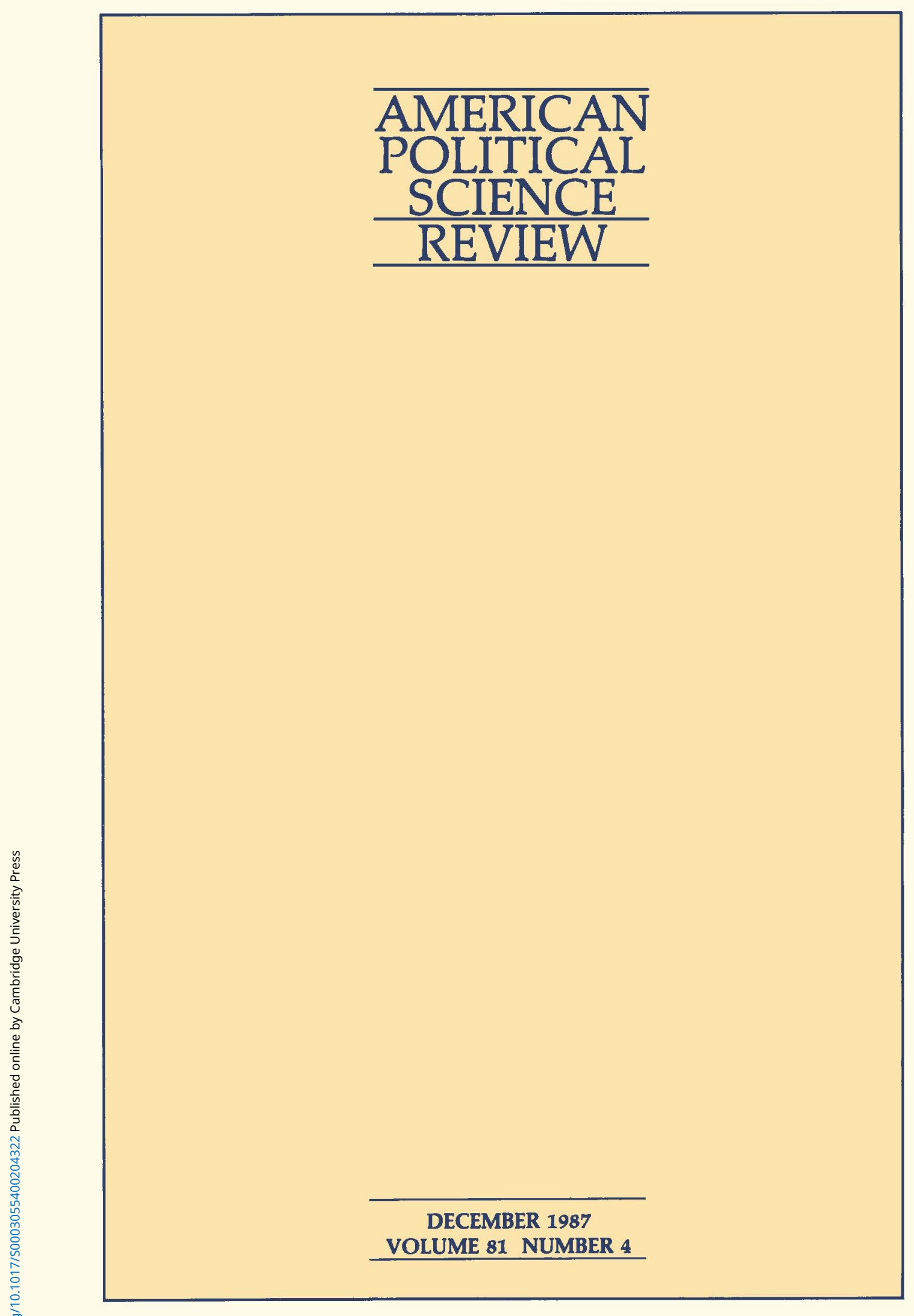




\title{
MANAGING EDITOR
}

\author{
Samuel C. Patterson \\ Department of Political Science
}

Ohio State University, 112 Derby Hall

Columbus, Ohio 43210-1373

BOOK REVIEW EDITOR

Helen M. Ingram

Department of Political Science

University of Arizona, Social Sciences 315

Tucson, Arizona 85721

\section{EDITORIAL BOARD}

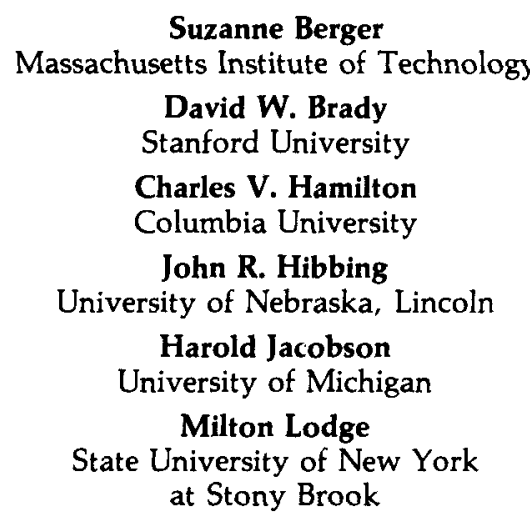

Suzanne Berger

David W. Brady

Stanford University

Charles V. Hamilton

Columbia University

hn R. Hibbing

Harold Jacobson

iversity of Michigan

University of New York

Stony Brook

Jean P. Kelly

Assistant Editor

Michael K. Lane

Copy Editor
John M. Orbell

University of Oregon

G. Bingham Powell, Jr.

University of Rochester

Harvey Starr

Indiana University

Dennis F. Thompson

Harvard University

John C. Wahlke

University of Arizona

Raymond Wolfinger

University of California,

Berkeley

\section{Michael S. Bailey \\ Valerie J. Martinez \\ Brian D. Ripley \\ Barbara Trish \\ APSR Interns}

Joan E. McLean

Editorial Assistant
The American Political Science Review (ISSN-00030554) appears in March, June, September, and December of each year. It is published by the American Political Science Association, 1527 New Hampshire Avenue, N.W., Washington, D.C. 20036, and sent to all members. Dues: Regular Members with income: under $\$ 20,000, \$ 40 ; \$ 20,000$ $\$ 29,000, \$ 50 ; \$ 30,000-39,999, \$ 65 ; \$ 40,000$ and over, \$75; Student Members (limited to 5 years), \$15; Retired Members, \$20; Life Members, \$1,000;
Institutional Members, $\$ 100$. Dues allocated for a subscription to the $A P S R$ : $\$ 10$ for individual members, $\$ 80$ for institutional members. Changes of address sent to the Membership Secretary of the APSA. Postmaster: Please send notification regarding undelivered journals to address above. Secondclass postage paid at Washington, D.C. and at additional mailing offices. Copyright 1987 by The American Political Sciençe Association. 


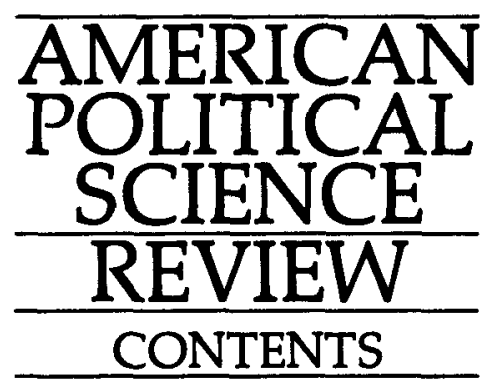

\section{ARTICLES}

Intimidation and the Symbolic Uses of Terror in the USSR

Donna Bahry \& Brian D. Silver . . . . . . . . . . . . . . . . . . . . 1065

How are Foreign Policy Attitudes Structured?

A Hierarchical Model

Jon Hurwitz \& Mark Peffley

Political Cleavages and Changing Exposure to Trade

Ronald Rogowski

Public Opinion and the U.S. Supreme Court:

FDR's Court-packing Plan

Gregory A. Caldeira

The Core of the Constitution

Thomas H. Hammond \& Gary J. Miller ... . . . . . . . . . . . . . 1155

Tocqueville's Constitutionalism

Robert P. Kraynak

Networks in Context: The Social Flow of

Political Information

Robert Huckfeldt \& John Sprague

Who Works with Whom? Interest Group Alliances

and Opposition

Robert H. Salisbury, John P. Heinz,

Edward O. Laumann \& Robert L. Nelson

Nationalization and Partisan Realignment in

Congressional Elections

Sadafumi Kawato

Democratic Representation and Partisan Bias in

Congressional Elections

Gary King \& Robert X Browning

CONTROVERSIES

Machiavelli's Paradox: Trapping or Teaching the Prince

John Langton \& Mary G. Deitz . . . . . . . . . . . . . . . . . . . . 1277

Value Change in Industrial Societies

Ronald Inglehart \& Scott C. Flanagan 


\section{RESEARCH NOTE}

Sophisticated Sincerity: Voting Over Endogenous Agendas

David Austen-Smith ................................ 1323 BOOK REVIEWS

Review Essays ....................................... 1337

Political Theory $\ldots \ldots \ldots \ldots \ldots \ldots \ldots \ldots \ldots \ldots \ldots \ldots \ldots \ldots \ldots \ldots, 1341$

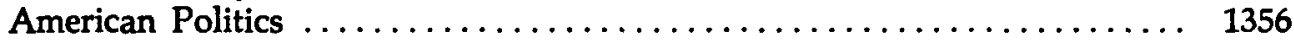

Comparative Politics .................................... 1382

International Relations $\ldots \ldots \ldots \ldots \ldots \ldots \ldots \ldots \ldots \ldots \ldots \ldots \ldots, 1411$

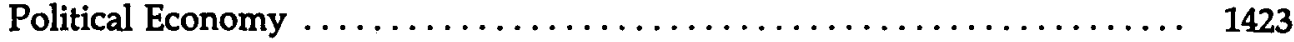

INDEX TO VOLUME $81 \ldots \ldots \ldots \ldots \ldots \ldots \ldots \ldots \ldots \ldots \ldots \ldots \ldots, 1437$

EFFECTIVE SEPTEMBER 1, 1987

All books for review should be sent to:

Helen M. Ingram, Book Review Editor

American Political Science Review

Department of Political Science

Social Sciences 315

University of Arizona

Tucson, Arizona 85721

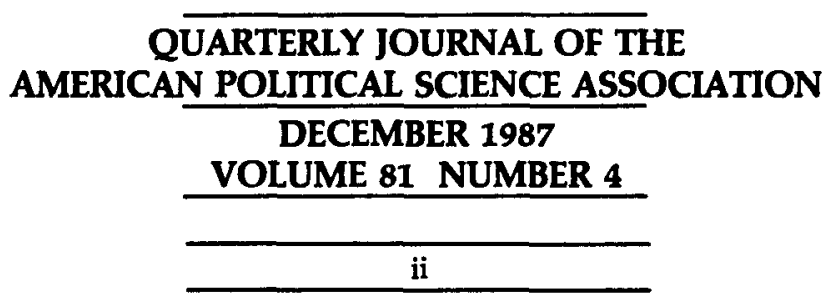




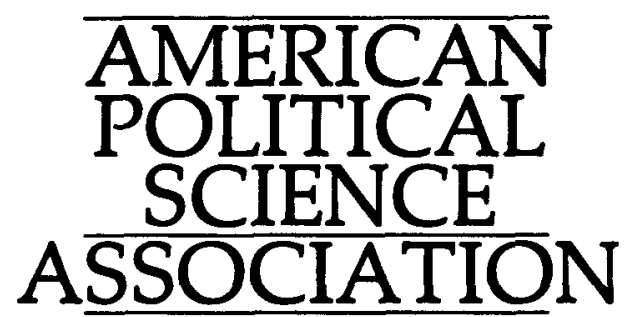

1527 New Hampshire Avenue, N.W.

Washington, D.C. 20036

PRESIDENT:

Kenneth N. Waltz

University of Califormia, Berkeley

PRESIDENT-ELECT:

Lucian W. Pye

Massachusetts Institute of Technology

VICE-PRESIDENTS:

Arend Lijphart

University of California, San Diego

Walter Murphy

Princeton University

Barbara Sinclair

University of Califormia, Riverside

SECRETARY:

James E. Anderson

Texas A\&M University

TREASURER:

Nancy H. Zingale

College of St. Thomas

EXECUTIVE DIRECTOR:

Catherine E. Rudder

PROGRAM CHAIRS:

John A. Ferejohn

Stephen D. Krasner

Stanford University

MANAGING EDITOR, APSR:

Samuel C. Patterson

Ohio State University
COUNCIL, 1986-88:

Robert H. Bates

Duke University

David W. Brady

Stanford University

Demetrios Caraley

Barnard College, Columbia University

Francis M. Carney

University of California, Riverside

Margaret Karns

University of Dayton

David Morgan

University of Liverpool

Mitchell Rice

Louisiana State University

Robert M. Rosenzweig

Association of American Universities

COUNCIL, 1987-89:

William I. Bacchus

Department of State

Donald Kinder

University of Michigan

Jane Mansbridge

Northwestern University

Dianne Pinderhughes

University of Illinois, Urbana-Champaign

Margaret E. Scranton

University of Arkansas, Little Rock

Mary Shanley

Vassar College

Richard A. Watson

University of Missouri, Columbia

Aristide Zolberg

New School for Social Research 


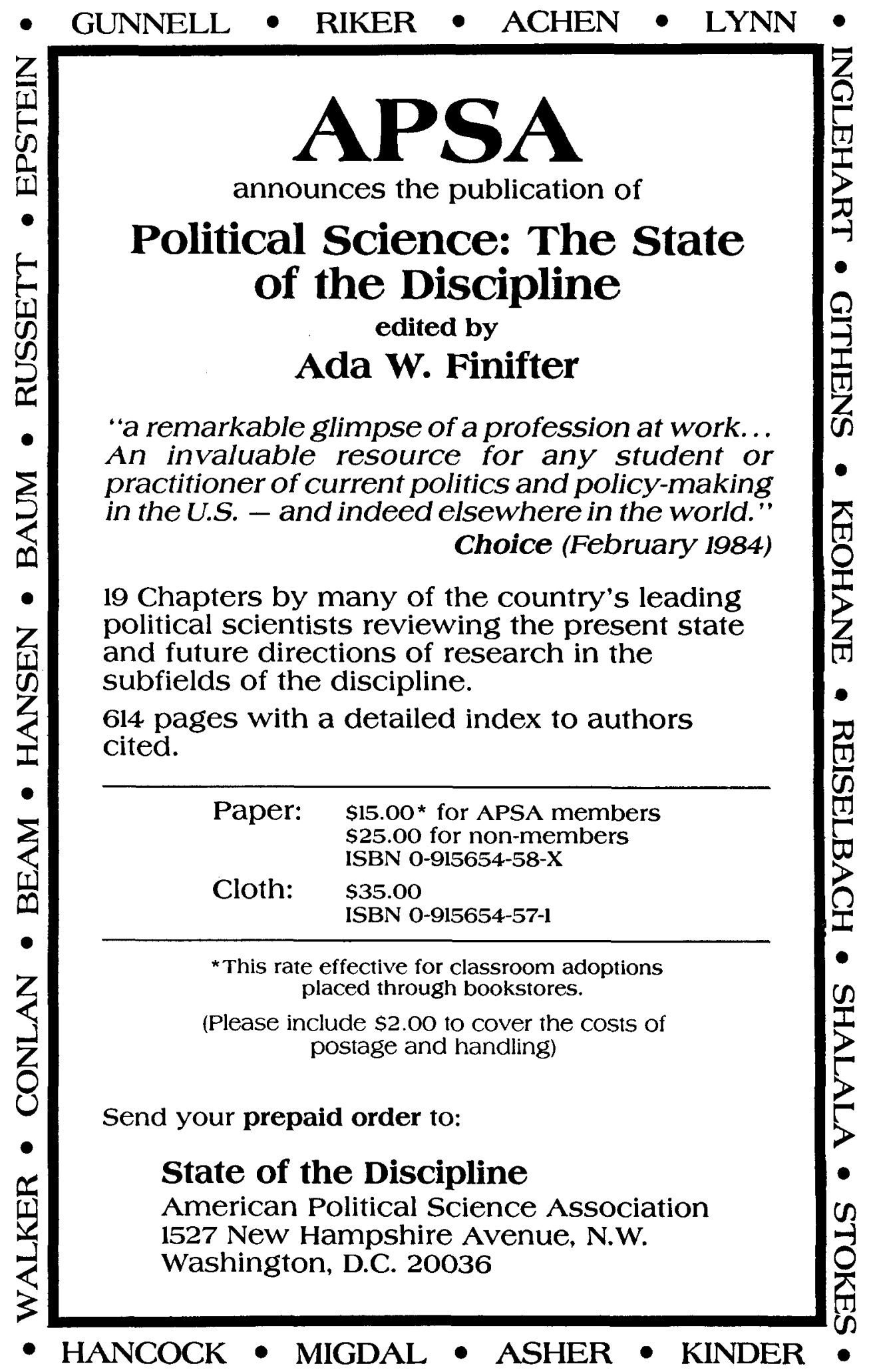

